\title{
PREDICTING ACADEMIC ACHIEVEMENT: THE ROLE OF MOTIVATION AND LEARNING STRATEGIES
}

\author{
Juliana Beatriz Stover, Agustín Freiberg Hoffmann \\ Buenos Aires University, Buenos Aires, Argentina \\ E-mail: julianastover@psi.uba.ar, afreiberg@psi.uba.ar
}

\author{
Guadalupe de la Iglesia, Mercedes Fernández Liporace \\ Buenos Aires University and National Research Council (CONICET), \\ Buenos Aires, Argentina \\ E-mail: gdelaiglesia@psi.uba.ar, mliporac@psi.uba.ar
}

\begin{abstract}
The aim of this study consists in testing a predictive model of academic achievement including motivation and learning strategies as predictors. Motivation is defined as the energy and the direction of behaviors; it is categorized in three types of motivation-intrinsic, extrinsic and amotivation (Deci \& Ryan, 1985). Learning strategies are deliberate operations oriented towards information processing in academic activities (Valle, Barca, González \& Núñez, 1999). Several studies analysed the relationship between motivation and learning strategies in high school and college environments. Students with higher academic achievement were intrinsically motivated and used a wider variety of learning strategies more frequently. A non-experimental predictive design was developed. The sample was composed by 459 students (55.2\% high-schoolers; $44.8 \%$ college students). Data were gathered by means of sociodemographic and academic surveys, and also by the local versions of the Academic Motivation Scale-EMA, Echelle de Motivation en Éducation (Stover, de la Iglesia, Rial Boubeta \& Fernández Liporace, 2012; Vallerand, Blais, Briere \& Pelletier, 1989) and the Learning and Study Strategies Inventory-LASSI (Stover, Uriel \& Fernández Liporace, 2012; Weinstein, Schulte \& Palmer, 1987). Several path analyses were carried out to test a hypothetical model to predict academic achievement (Kline, 1998). Results indicated that selfdetermined motivation explained academic achievement through the use of learning strategies. The final model obtained an excellent fit $(\chi 2=16.523, d f=6, p=0.011 ; G F I=0.987 ; A G F I=0.955 ;$ SRMR=0.0320; $N F I=0.913 ; I F I=0.943 ; C F I=0.940)$. Results are discussed considering Self Determination Theory and previous research.
\end{abstract}

Key words: academic achievement, learning strategies, motivation, students.

\section{Introduction}

Examining variables associated with academic achievement involves an extremely complex issue, which have been the object of attention for Educational Psychology in the last century. These studies were originally focused on intellectual abilities hypothetically related to students' achievement (e.g., Binet, 1903), changing later to current approaches, considering non-intellective 
factors, where interventions seem to be more probably successful (Casillas et al., 2012; Richardson, Abraham \& Bond, 2012). In the local environment, the topic acquires a huge importance because of the concerning about low grades, high percentages of academic dropout in high school and colleges, as well as difficulties in adaptation to university requirements (e.g., Goldenhersh, Coria \& Saino, 2011; Ministry of Education, 2010, 2012; Oliver et al., 2011; OEDC, 2013). Within variables potentially related to academic achievement, this paper will centre its attention in academic motivation and learning strategies.

Regarding motivation, the Self-Determination Theory is currently one of the most influential approaches in force (Deci \& Ryan, 1985). It has been developed as a macro-theory of human motivation, which intends a general comprehension of behaviors, feasibly pertinent to every human context, and also useful in diverse cultures. These notes allow its wide diffusion due to its applicability to different domains, such as education, sports, occupational and clinical milieu (e.g., Deci \& Ryan, 2004). Deci and Ryan assert that a psychological theory is motivational only if it takes into account the energy and the direction of behaviors. Energy mainly implies needs. Direction includes the processes taking place in the organism, giving significance to internal and external stimulation, and guiding actions towards the satisfaction of those needs.

Focusing on the educational field, authors propose a model containing three types of motivation -intrinsic (IM), extrinsic (EM) and amotivation (A), placed along a continuum of selfdetermination. Intrisically motivated (IM) behaviors, where activities constitute the very same goal themselves, were divided into other three sub-types, considering their orientation: when they pursue stimulating experiences - the individual is involved in a given activity to perceive pleasant sensations, such as aesthetic, intellectual, sensitive, etc.; when the person is focused towards accomplishments - behaviors are addressed to satisfaction implied in creation or in self-improvement; and when the individual is oriented by knowledge goals -developing an activity because of the pure pleasure experienced when something new is learnt (Vallerand et al., 1989). On the contrary of IM, EM practices become means pursuing a goal. In this case, along a continuum of internalization, four types of regulation in EM are distinguished: EM external -behaviors developed to avoid punishments or to obtain rewards-; introjected- avoidance of guilt or anxiety, or actions directed to increase self-esteem-; EM identified -the person chooses and valuates the activities as being own, though they continue being determined by external motives-. The fourth type -EM integrated- appears during adulthood and becomes in force when individual needs and values coincide with those socially expected behaviors, beginning to constitute a part of one's self. The more internalized the EM, more autonomous will be the subject when developing these activities (Deci \& Ryan, 1985; Ryan \& Deci, 2000).

When the whole process described before does not take place, amotivation arises. It is defined as the complete lack of motivation. Individuals do not regulate their behaviors because they experience an absence of purposes, they do not perceive any chance of changing events, they do not valuate the activity in a positive way, feeling they are no competent enough, hence expecting no positive results at all.

The association between academic achievement and motivation comes up as a matter of interest for researchers. Vallerand, Fortier and Guay (1997) found that students who dropped out school were more amotivated and experienced less IM, as well as less influence of the more autonomous types of EM. Otis, Grouzet and Pelletier (2005), and Ratelle, Guay, Vallerand, Larose and Senécal (2007) reported a better academic adjustment (less absenteeism and less intentions of dropout) in those who possessed an autonomous regulation. Allowing for grades, researchers showed that students who exhibited a more autonomous regulation obtained better results, as well as better achievement in standardized performance tests (e.g., Grolnick, Ryan \& Deci, 1991; Guay \& Vallerand, 1997, Fortier, Vallerand \& Guay, 1995; Sheldon \& Krieger, 2007). It was also found that those students with a more autonomous profile enjoyed classes in a higher proportion, and showed more psychological well-being (e.g., Burton et al., 2006; Jang et al., 2009; Liu et al., 2009; Mouratidis et al., 2013; Ng et al., 2012).

Referring now to the second variable of interest, learning strategies (LS), the literature on the subject shows a variety of current definitions (Montanero \& León, 2001; Valle et al., 1999). Dansereau (1985), for instance, understands them as a group of steps which facilitate the selec- 
tion, storage, manipulation and use of information. Nisbet and Shucksmith (1987) describe the concept as integrated sequences consisting in procedures or activities which pursue the goal Vol. 8, No. 1, 2014 of enabling acquisition, storing and employment of knowledge. Monereo (1990) defines them as planned behaviors, directed to select and to organize different mechanisms of cognitive, affective and behavioral kinds, with the aim of coping with problematic situations - global or specific- in learning environments. In the same direction, Weinstein, Husman and Dierking (2000) allude to an integrated cluster of thinking, beliefs, emotions and behaviors which act as catalysts in processes of comprehension, acquisition, recall and ulterior transference of new knowledge and, in some cases, of new abilities. All these meanings, despite their diversity, still have something in common: every author states that LS are propositive operations structured towards knowledge processing.

While a plurality of definitions is observed, several classifications are detected (e.g., Beltrán, 1996; Dansereau, 1985), agreeing all of them in categorizing LS as cognitive, metacognitive and of managing resources or support (Valle et al., 1999). The first group refers to integrating novel information to previous knowledge by means of coding, comprehension and evocation. The second group allude to planning, control and assessment of the students' own mental processes, promoting the regulation of their cognitions to get some learning goals. In the third case, strategies to manage resources and support include motivational, attitudinal and affective aspects, which act improving material and psychological circumstances where learning takes place.

Several studies analysed the relationship between motivation and learning strategies in high school and college milieus. Students with higher grades used a wider variety of LS more frequently (e.g, Badenier, 2003; Camarero Suárez, Martín del Buey \& Herrero Diez, 2000; Cardozo, 2008; Cano, 2006; de la Fuente \& Justicia, 2003; Gargallo, Suárez \& Ferreras, 2007; Liu, 2009; Loong, 2012; Martín et al., 2008; Yip, 2007). Besides, interactions with some other academic factors were explored, such as types of goals, expectations towards every subject, self-esteem and academic anxiety (e.g., Furlan, Sánchez \& Heredia, 2009; Gázquez et al., 2006; Rinaudo, Chiecher \& Donolo, 2003).

The joint assessment of motivation and strategies has favored stating predictive models of academic achievement from different theoretical frameworks. Pokay and Blumenfeld (1990) reported in a well known research, that motivation -defined as expectations- influenced in the use of LS, and they affected grades obtained in Maths. From Self-Determination approach, Vansteennkiste, Zhou, Lens and Soenens (2005) found that self-determined motivation had an effect on the use of LS, and they finally improved grades in English. A recent study informed similar results: autonomous motivation influenced strategies of deep processing, and then they enhanced grades in general (Kusurkar et al., 2012).

Since previous studies have established that motivation influences the use of LS, and they impact directly on academic achievement, the aim here sought is examining a predictive model of academic achievement including the variables mentioned above. The present study intends to detect if motivation influences learning strategies, and if they have any repercussions on academic achievement in high school and college students from Buenos Aires, Argentina. The questions which oriented this research were as follows: Which is the role of motivation on academic achievement in high school and college students? Does every learning strategy influence academic achievement in the same way or there are specific strategies which seem to be more influential than the rest of them?

\section{Methodology of Research}

\section{General Background of Research}

A non-experimental, transversal design was developed -which means that data were gathered in a unique moment, during 2013-, configuring a predictive study (Hernández-Sampieri, FernándezCollado \& Lucio, 2006). 
470 cases were gathered, dismissing 11 of them since these respondents left various unanswered items ( 7 high-schoolers and 4 collegers). Hence, the final sample was composed by 459 students $(55.2 \%$ high-schoolers, $44.8 \%$ college students). The high school group included 251 students (37.9\% males, $62.1 \%$ females), with ages between 13 and 20 years old ( $M=15.37$; S.D. $=1.59)$. Regarding courses, percentages were as follows: $29.1 \% 1^{\text {st }}$ year, $21.1 \% 2^{\text {nd }}$ year, $18.3 \%$ $3^{\text {rd }}$ year, $22.3 \% 4^{\text {th }}$ year, and finally, $9.2 \%$ for the 5 th year. The college group consisted of 208 students $(34.1 \%$ males, $65.9 \%$ females $)$, from 18 to 35 years $(\mathrm{M}=22.98$; S.D. $=3.83)$. Students attended to diverse careers (31.3\% Psychology, 32.7\% Medicine, 21.6\% Veterinary Sciences, 9.6\% Industrial Engineering, 4.8\% Chemistry).

\section{Instruments and Procedures}

- Local version of the Academic Motivation Scale-EMA, Echelle de Motivation en Éducation- (Vallerand et al., 1989), constituted by the following scales: IM-Stimulating (IMs), IMKnowledge (IMk), IM-Accomplishment (IMa), EM Identified Regulation (EMid), EM Introjected Regulation (EMint), EM External Regulation (EMex) and Amotivation (A), as established by the original model by Deci and Ryan (1985) and Vallerand et al. (1989). The one representing Integrated Regulation has been excluded due to it is considered as arising during adulthood, being most participants adolescent or young adults. The local short version is composed of 27 items with a 4-point Likert response (Stover, de la Iglesia, Rial Boubeta \& Fernández Liporace, 2012). Two versions are available: one for high-schoolers and another one for college students, with identical contents, but adapted to every academic context.

- Local version of Learning and Study Strategies Inventory -LASSI- (Stover, Uriel \& Fernández Liporace, 2012; Weinstein, Schulte \& Palmer, 1987). The local short version, designed to be used in both educational levels was employed. It consists of 21 items, distributed into six scales: Organization and Planning (OP) assesses organization, concentration, and time management in academic activities; Abilities to Prepare Exams (APE) valuates the use of testing strategies, comprehension of instructions and anticipation of contents that will be tested in exams; Motivation (M) analyses perseverance and dedication in studies; Resources for Learning (RL) contemplates the use of graphic means (tables, conceptual maps, highlights-underlining); Control and Consolidation Strategies (CCE) assesses the revision of academic materials and contents; and finally, Abilities to Rank Information (ARI) explores the capacity to select the important information to be learnt.

Participants were selected by means of a non-random procedure in public and private institutions (high schools and colleges). Three high schools were selected -two private and one public, and also four Colleges of University of Buenos Aires -Psychology, Maths and Natural Sciences, Engineering, Veterinary Sciences- and one private-Medicine-. Collective data gathering took place in classrooms during habitual class schedule. Participation was voluntary, allowed by informed consent. Anonymity was guaranteed as well as data confidentiality. When students were underage, parents also gave their consent. Besides, a sociodemographic and academic survey were employed. The first one collects personal information. The last one enquires about academic data (school, course, career, type of institution). As for academic achievement, information on different aspects was required in order to obtain several complex indicators of it. In high school, data regarding failed classes, grades obtained (in average) in core courses, and classes taken twice because of failure at the first attempt, were collected. In college students, information concerning continuity in the career, failed final-term exams, courses successfully passed, F-grades at any class, dropout by absenteeism, courses approved without a final exam, dropout in courses, lack of regularity, etc., was required. This variety of data allows to analyse them separately -in order to identify the best indicators of achievement for each educational level-, and also to use them to split the sample by high, average and low achievement (Stover, 2012). 
First, those students with low and high academic achievement were selected from the whole sample in order to maximize differences within groups.

In order to include motivation in this kind of analyses, the calculation of a Self-Determined Motivational index is often a good option (e.g., Faye \& Sharpe, 2008; Fortier, Vallerand \& Guay, 1995; Vallerand, Fortier \& Guay, 1997). This index gives a higher weight to intrinsic scales compared with the extrinsic ones, which receive lower weights in the total score, leaving aside the sum of EM Introjected Regulation, in order to balance the number of intrinsic and extrinsic dimensions (Fortier, Vallerand \& Guay, 1995). Its removal has been examined in previous studies, verifying no-differences in estimated statistics when it was considered, in comparison with occasions when it was not taken into account (Faye \& Sharpe, 2008). This index is obtained by means of the following equation:

$$
[(2 *(I M s+I M k+I M a) / 3+E M i d-((E M e x+2 *(A))]
$$

Regarding that in the process of local adaptation of the scale an item was left out in EM External Regulation (Stover et al., 2012), when calculating the equation mentioned above, an item was added to EM Introjected Regulation. Item number 5 was the adequate option, in view of its better psychometric behavior in high school and in college level as well (with respective loads of .667 and .571). This way, the equation here used resulted as follows:

$$
[(2 *(I M s+I M k+I M a) / 3+E M i d-((\text { item } 5+E M e x+2 *(A))]
$$

Several path analyses were carried out to test a hypothetical model to predict academic achievement (Kline, 1998). Estimations were developed using Generalized Least Squares (GLS), due to quantitative variables included showed a lack of normality. Complementarily, a bootstrap procedure was applied, as well as a Bayesian estimation, to analyse results stability, viewing the inclusion of academic achievement as a dichotomous variable (Byrne, 2009).

\section{Results of Research}

In the first place, students with low and high achievement were selected. For high school, students with low achievement were defined as follows: 1) everyone who had to take a course twice or more times because of failure or dropout, 2) students in the $1^{\text {st }}$ course with low average grades -below the $25^{\text {th }}$ percentile, 3 ) students from $2^{\text {nd }}$ to $5^{\text {th }}$ course with a higher number of failed classes - above the $75^{\text {th }}$ percentile. High-achievement group, on the contrary, included all students who attended to courses just once (they did not fail any class), and at the same time: 1) within students of the $1^{\text {st }}$ course, those who had high average grades -above the $75^{\text {th }}$ percentile; 2 ) from $2^{\text {nd }}$ to $5^{\text {th }}$ course, those with none or less classes failed-below the $25^{\text {th }}$ percentile. Worthy to note that in the Argentinean educational system freshmen ( $1^{\text {st }}$ year-students) have not had the chance to owe courses yet failed, so the ratings were used to form groups, whereas in the remaining courses owed classes were selected due to they represent properly the achievement in previous years.

At the college level, the low-achievement group was composed by students above the $75^{\text {th }}$ percentile, resulting in the division of the number of F-grades by the amount of courses attended, while those with high achievement were defined by their location below the $25^{\text {th }}$ percentile.

A previous study about the behavior of LS around Academic Achievement was developed in order to select strategies to be included in path analysis. Using a multiple logistic regression (backward stepwise), Organization and Planning $(\beta=0.119 ; \mathrm{p}<0.001)$, Abilities to Prepare Exams $(\beta=0.233 ; p=0.003)$, Motivation $(\beta=0.297 ; p=0.001)$ and Resources for Learning $(\beta=-0.180$, $\mathrm{p}=0.002$ ) remained in the model. Given that the link of Self-Determined Motivation with the LS called Motivation would be examined, it is important to recall that the last one assesses persistence and dedication in studies, while the first one allude the motives that move the actualisation of academic activities. 
In order to establish the sense of the effects, it was considered that motivation has been posed as the source of energy and direction in behaviors (Ryan \& Deci, 2000), hence, it is supposed that it influences the use of strategies and they, finally, have an effect on academic achievement (Pokay \& Blumenfeld, 1990). Figure 1 presents the hypothetical model.

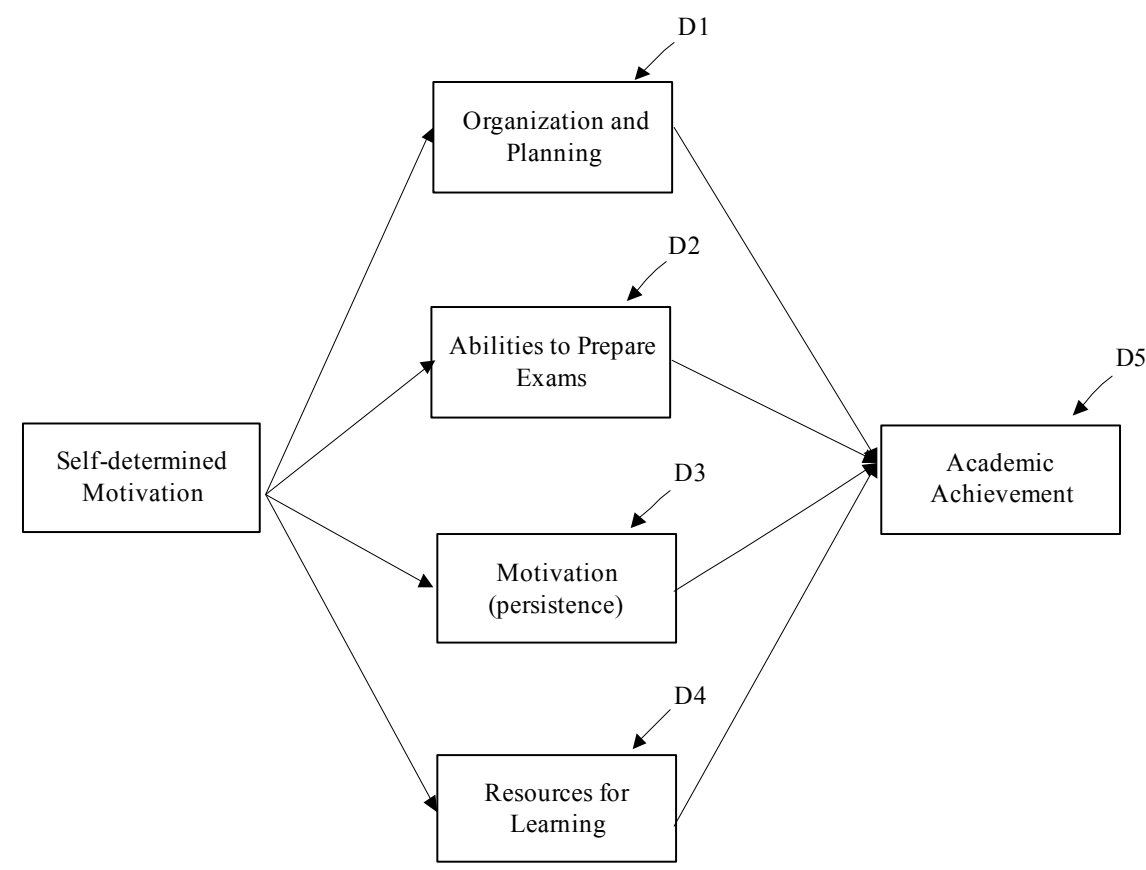

Figure 1: Hypothetical model to predict academic achievement.

The assumption of multivariate normality was verified, since multivariate curtosis values below 5.99 were found $(\mathrm{CR}=-3.447)$. However, as Table 1 shows, the same did not happen with univariate normality, given that most of the asymmetry and curtosis indexes were above the cutoff point of \pm 1.96 (Lévy \& Varela Mallou, 2006). Therefore, Generalized Least Squares (GLS) estimation method, recommended for quantitative variables when assumptions compliance is not verified, was employed. To improve the lack of univariate normality, a bootstrap procedure generating 1000 subsamples was developed. Considering the inclusion of a dichotomous variable -academic achievement (low versus high), a Bayesian estimation was carried out in order to examine the stability of estimated parameters when a distribution for the own variable was generated (Byrne, 2009).

Table 1. Variables used in path analysis.

\begin{tabular}{|c|c|c|c|c|c|c|c|}
\hline & \multirow{2}{*}{$M(S D)$} & \multicolumn{3}{|c|}{ AsSimetrY } & \multicolumn{3}{|c|}{ curtosis } \\
\hline & & Statistic & S.E. & $\underset{(G 1)}{Z}$ & Statistic & S.E. & Z (G1) \\
\hline Self-determined Motivation & $54.57(17.07)$ & -0.251 & 0.118 & -2.27 & -0.442 & 0.235 & -1.880 \\
\hline Organization and Planning & $19.02(3.93)$ & -0.251 & 0.118 & -2.127 & -0.617 & 0.235 & -2.625 \\
\hline Abilities to Prepare Exams & $10.08(1.58)$ & -0.7740 & 0.0118 & -6.305 & 0.030 & 0.235 & 0.127 \\
\hline Motivation & $8.96(1.97)$ & -0.0332 & 0.118 & -2.20 & -0.664 & 0.235 & -2.825 \\
\hline Resources for Learning & $4.88(1.97)$ & 0.102 & 0.118 & 0.864 & 1.169 & 0.235 & 4.974 \\
\hline
\end{tabular}


The estimation of the initial model did not presented adequate values $\left(\chi^{2}=68.915\right.$, $\mathrm{df}=7$, $\mathrm{p}=0.000 ; \mathrm{GFI}=0.946 ; \mathrm{AGFI}=0.839 ; \mathrm{SRMR}=0.0860 ; \mathrm{NFI}=0.638 ; \mathrm{IFI}=0.663, \mathrm{CFI}=0.647)$. Every standardized regression weight resulted statistically significant. Within modification indexes, values above 3.84 were detected (Lévy \& Varela Mallou, 2006). One of them indicated the convenience of adding an effect from Organization and Planning towards Abilities to Prepare Exams (MI=14.984), and also another one from Organization and Planning towards Motivation $(\mathrm{MI}=11.380)$. That seemed logical if it was considered that Organization and Planning was the dimension which explained the major percentage of variance in exploratory studies in local adaptations of the scale (Fernández Liporace, Scheinsohn \& Uriel, 2010).

After introducing all those modifications the model fit improved remarkably $\left(\chi^{2}=15.323\right.$, $\mathrm{df}=5, \mathrm{p}=0.009 ; \mathrm{GFI}=0.988 ; \mathrm{AGFI}=0.950 ; \mathrm{SRMR}=0.0332 ; \mathrm{NFI}=0.920 ; \mathrm{IFI}=0.944, \mathrm{CFI}=$ 0.941). Examining parameters, the effect from Self-Determined Motivation towards Abilities to Prepare Exams had no statistical significance $(\mathrm{p}=0.271)$; for that reason it was left aside. The obtained fit did not exhibit substantial changes $\left(\chi^{2}=16.523, \mathrm{df}=6, \mathrm{p}=0.011\right.$; $\mathrm{GFI}=0.987$; $\mathrm{AGFI}=0.955$; $\mathrm{SRMR}=0.0320 ; \mathrm{NFI}=0.913 ; \mathrm{IFI}=0.943 ; \mathrm{CFI}=0.940)$. To determine which model would be selected, the change in estimations was analysed, but $\chi^{2}$ was not significant $\left(\Delta \chi^{2}=1.207 ; \mathrm{p}=0.250\right)$. Given these findings, the most parsimonious solution was the call, where the effect towards Abilities to Prepare Exams was eliminated. Comparing this model with the one initially proposed (Figure 1), the change in $\chi^{2}$ resulted then statistically significant $\left(\Delta \chi^{2}=53.592 ; \mathrm{p}=0.001\right)$.

Standardized parameters and complementary analyses of bootstrap and Bayesian estimations are presented in Table 2, and the resulting model is exhibited in Figure 2.

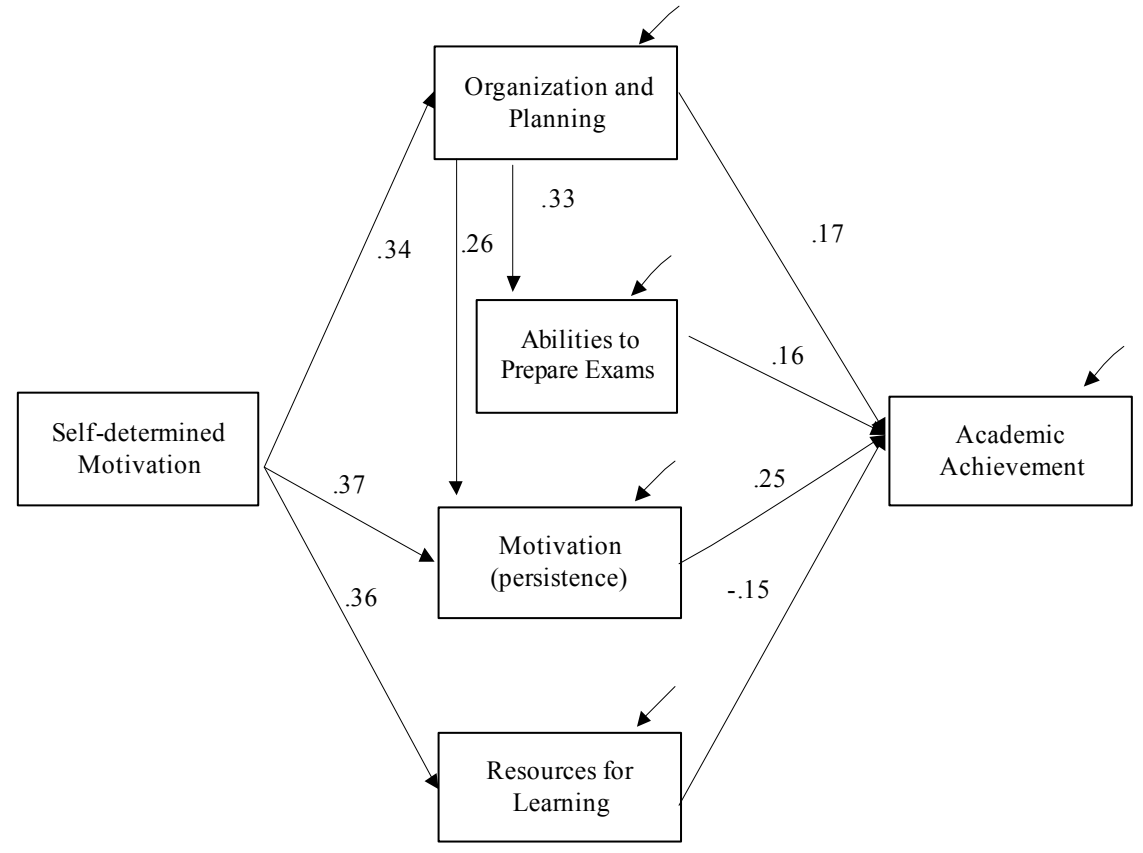

Figure 2. Estimated model to predict academic achievement.

Table 2. Model to predict academic achievement. The parameters obtained with bootstrap (mean values and $95 \%$ confidence intervals) and Bayesian estimation.

\begin{tabular}{|c|c|c|c|c|c|c|c|}
\hline \multirow{2}{*}{ Exogenous } & \multirow{2}{*}{ Endogenous } & \multicolumn{3}{|c|}{$\begin{array}{l}\text { Standardized } \\
\text { parameters }\end{array}$} & \multirow{2}{*}{$p$} & \multicolumn{2}{|c|}{$\begin{array}{l}\text { Non-standardized } \\
\text { parameters }\end{array}$} \\
\hline & & M & IL & SL & & GLS & BAYES \\
\hline $\begin{array}{l}\text { Self-determined } \\
\text { Motivation }\end{array}$ & $\begin{array}{l}\text { Organization and } \\
\text { Planning }\end{array}$ & 0.341 & 0.258 & 0.423 & 0.012 & 0.079 & 0.076 \\
\hline
\end{tabular}




\begin{tabular}{|c|c|c|c|c|c|c|c|c|}
\hline \multirow{2}{*}{ Exogenous } & & \multirow{2}{*}{ Endogenous } & \multicolumn{3}{|c|}{$\begin{array}{l}\text { Standardized } \\
\text { parameters }\end{array}$} & \multirow{2}{*}{$p$} & \multicolumn{2}{|c|}{$\begin{array}{l}\text { Non-standardized } \\
\text { parameters }\end{array}$} \\
\hline & & & M & IL & SL & & GLS & BAYES \\
\hline $\begin{array}{l}\text { Self-determined } \\
\text { Motivation }\end{array}$ & $\rightarrow$ & Motivation & 0.374 & 0.280 & 0.466 & 0.007 & 0.041 & 0.043 \\
\hline $\begin{array}{l}\text { Self-determined } \\
\text { Motivation }\end{array}$ & $\rightarrow$ & $\begin{array}{l}\text { Resources for } \\
\text { Learning }\end{array}$ & 0.355 & 0.247 & 0.434 & 0.026 & 0.044 & 0.039 \\
\hline $\begin{array}{l}\text { Organization and } \\
\text { Planning }\end{array}$ & $\rightarrow$ & $\begin{array}{l}\text { Abilities to Prepare } \\
\text { Exams }\end{array}$ & 0.328 & 0.247 & 0.411 & 0.018 & 0.132 & 0.126 \\
\hline $\begin{array}{l}\text { Organization and } \\
\text { Planning }\end{array}$ & $\rightarrow$ & Motivation & 0.257 & 0.158 & 0.374 & 0.006 & 0.130 & 0.130 \\
\hline $\begin{array}{l}\text { Organization and } \\
\text { Planning }\end{array}$ & $\rightarrow$ & $\begin{array}{c}\text { Academic } \\
\text { Achievement }\end{array}$ & 0.174 & 0.063 & 0.270 & 0.018 & 0.043 & 0.048 \\
\hline $\begin{array}{l}\text { Abilities to Prepare } \\
\text { Exams }\end{array}$ & $\rightarrow$ & $\begin{array}{c}\text { Academic } \\
\text { Achievement }\end{array}$ & 0.163 & 0.077 & 0.244 & 0.005 & 0.101 & 0.089 \\
\hline Motivation & $\rightarrow$ & $\begin{array}{c}\text { Academic } \\
\text { Achievement }\end{array}$ & 0.250 & 0.153 & 0.342 & 0.006 & 0.123 & 0.120 \\
\hline $\begin{array}{l}\text { Resources for } \\
\text { Learning }\end{array}$ & $\rightarrow$ & $\begin{array}{c}\text { Academic } \\
\text { Achievement }\end{array}$ & -0.153 & -0.230 & -0.058 & 0.019 & -0.076 & -0.070 \\
\hline
\end{tabular}

Self-determined Motivation explained Academic Achievement through the use of LS. Its indirect effect, mediated by Organization and Planning was $\beta=0.059\left(0.341^{*} 0.174\right)$. For the Motivation-LS, the result was $\beta=0.092(0.374 * 0.250)$. Finally, Resources for Learning obtained the following: $\beta=-0.054\left(0.355^{*}-0.153\right)$. This way, the total effects of Self-Determined Motivation on achievement were $\beta=0.250$. The Organization and Planning-LS had a direct effect of $\beta=0.174$, and two indirect effects. One of them was mediated by Abilities to Prepare Exams, and resulted in $\beta=0.053\left(0.328^{*} 0.163\right)$, and the remaining, mediated by the Motivation-LS was $\beta=0.064\left(0.257^{*} 0.250\right)$. Worthy to note that the betas coefficients informed before $(\beta)$ result from the multiplication of the betas corresponding to predictors involved in the model. Adding the direct effect and the indirect ones, the influence of Organization and Planning was $\beta=0.290$. Valuating direct effects of the remaining strategies, the highest value appeared in Motivation ( $\beta=0.250)$, followed by Abilities to Prepare Exams $(\beta=0.163)$, and Resources for Learning ( $\beta=-$ $0.153)$, whose influence was negative.

\section{Discussion}

This study intended to analyse academic motivation and learning strategies as predictors of academic achievement. By means of a path analysis, a model to predict academic achievement, based on theoretical and statistical aspects -regression analysis- was tested. An effect of self-determined motivation on four learning strategies - Organization and Planning, Abilities to Prepare Exams, Motivation, Resources for Learning - was posed and, after that, the influence of those strategies on academic achievement was also hypothesized. After developing an estimation by Generalized Least Squares and complementary analyses which employed bootstrap and Bayesian estimations, most of the proposed relationships were verified. Only two re-specifications were required. The effect from Self-Determined Motivation towards Abilities to Prepare Exams was eliminated, and two effects were added, departing from Organization and Planning towards Abilities to Prepare Exams, as well as towards Motivation -worthy to note that the last one refers to the persistence in academic activities, and it does not allude motivation as a concept.

This way, the model fit explained the influence of self-determined motivation on academic 
achievement, through learning strategies. This coincides with that asserted by Ryan and Deci (2000), who stated that motivation concerns to energy, direction and goals of behaviors. Thereby, the interpretation indicates that academic motivation energizes the use of learning strategies. These findings run in the same direction with previous studies, both classic and recent ones, even despite of the use of different theoretical approaches (e.g.; Kusurkar et al., 2012; Pokay \& Blumenfeld, 1990; Vansteennkiste et al., 2005).

Analysing the effects of learning strategies, Organization and Planning in students plays a central role, taking into account its direct influence, as well as by means of the Ability to Prepare Exams and the Motivation strategies- which have a direct relationship with academic achievement. This implies that designing a study schedule, organizing it, anticipating possible evaluations, adjusting oneself to that schedule and persevering in it will feasibly improve academic achievement. On the contrary, the strategy called Resources for Learning -meaning the use of graphics or conceptual maps as means to help students to learn -, for instance, exhibited a negative effect on achievement -i.e. the more employment of those resources, the lower achievement would be-. This could be interpreted considering, for example, the quality of conceptual maps designed by the students. A possible hypothesis could state that, when they design those maps, they do not reach to include central contents, a fact that eventually could be expressed by worst achievements. A deep exam of the process involved in the proper use of those maps or graphics appears as a reasonable previous step before any strong conclusion. Of course, these speculations must be examined in future studies.

Regarding to applied transference, these results acquire relevance when examining the growing concerns about academic achievement and the pursued articulation within the educational levels here analysed: high school and college (e.g., Goldenhersh, Coria \& Saino, 2011; Ministry of Education, 2010, 2012; Oliver et al., 2011). Local researchers have verified correlations amongst motivation, learning strategies and academic achievement, notwithstanding they did not analyse the direction of possible effects by means of structural equation models (Rinaudo et al., 2003, 2006).

Beginning with the valuation of methodological limitations in the present study, the transversal design must be pointed out at first: it implies the impossibility of developing causal inferences. Another limitation rests in the sample selection, which happened to be non-probabilistic and simple. This weakness in selection was intended to be improved by means of a bootstrap procedure, involving a re-sampling of cases. Examining the composition of the groups contained in the sample, another weakness is noticed in data gathering, done exclusively in schools and colleges where the medium socio-economical level prevails. Consequently, generalization of results must be restricted to students with similar sociodemographic and academic notes than participants.

Considering means for data gathering, sociodemographic and academic surveys as well as psychometric scales used a self-report modality, implying potential distortions in answers. Though, despite mentioned above, previous studies found that sociodemographic and academic data provided by the students use to be in correspondence with those obtained from their family and academic institutions (Looker, 1989; Vittorio et al., 2008). It is expected, besides, that added than the big sample size, it could help to minimize the effect of distorted answers. Plus, it seems very probable that the voluntary participation could diminish this distortive effect.

As for future research lines, the amplification of the predictive model for academic achievement would be desirable, in order to include some aspects of Self Determination Theory not considered in the present study - such as psychological needs-. On the other hand, the addition of other variables linked to academic performance - for instance, psychological adjustment- also appears as a reasonable option (e.g., Burton et al., 2006; Ng et al., 2012). Longitudinal designs would be a matter of interest, allowing the assessment of changes through different educational trajectories. The applied benefit will be perceived in students' everyday life, since an effective education facilitates their integration into the labor market, as well as a general improvement in their life quality (Formichella, 2009; García de Fanelli \& Jacinto, 2010). 


\section{Conclusions}

About the transference of novel knowledge, the main contribution rests in the depiction of motivation and learning strategies, related to academic achievement in high school and college students, by means of multivariate analyses. Also, the use of a Self-Determined Motivation index allowed analysing the students' motivation in a global way, as it appears in everyday life, instead of by means of separate subtypes. Motivational behaviors happen as a whole and splitting them by subtypes only intends to be useful to facilitate the comprehension of such complex notion. Actual behaviors do not permit this conceptual segmentation in an easy way.

The importance of this research lies on the verification that motivation and learning strategies are relevant for students' achievement: self-determined motivation seems to favor the use of learning strategies. This result suggests that, in the daily academic work, training students to develop learning strategies comes up as a main pedagogical goal. Notwithstanding, paying attention to motivational aspects arises as a central issue. About strategies, being able to plan and to organize academic activities seems to be the key for a successful achievement, due to it has an impact on performance and also on other two strategies: the ability to prepare exams and persistence as well.

Having access to this information will help to improve in both educational levels those particular notes linked to success in studies. Knowing these profiles will be helpful in the design of interventions, adequate to those specific notes exhibited by local students, but also useful to identify those particular profiles under potential academic risk (by failure, dropout, lack of motivation or lack of extrinsic motivation, inadequate use of learning strategies, etc.), in view of the concerns about a low academic achievement in high school and college levels.

\section{References}

Badenier, C. (2003). Confiabilidad y validez del Learning and Study Strategies Inventory en una muestra de estudiantes de la región metropolitana [Reliability and validity of the Learning and Study Strategies Inventory in a sample of students of the metropolitan region]. Psykhe, 12 (2), 193-206.

Beltrán, J. A. (1996). Estrategias de aprendizaje. En J. Beltrán \& C. Genovard (Eds.), Psicología de la instrucción I [Learning strategies]. In J. Beltrán \& C. Genovard (Eds.), Psychology of Instruction, I] (pp. 285-298). Madrid: Síntesis.

Binet, A. (1903). L'étude expérimentale de l'intelligence [The experimental study of intelligence]. Paris: L' Harmattan.

Burton, K. D., Lydon, J. E., D’Alessandro, D. U., \& Koestner, R. (2006). The differential effects of intrinsic and identified motivation on well-being and performance: Prospective, experimental and implicit approaches to self-determination theory. Journal of Personality and Social Psychology, 91 (4), 750-762. doi: 10.1037/0022-3514.91.4.750.

Byrne, B. M. (2009). Structural equation modeling with AMOS. New York: Routledge.

Camarero Suárez, F., Martín del Buey, F., \& Herrero Diez, J. (2000). Estilos y estrategias de aprendizaje en estudiantes universitarios [Styles and learning strategies in college students]. Psicothema, 12 (4), 615-622.

Cano, F. (2006). An in-depth analysis of the Learning and Study Strategies Inventory (LASSI). Educational and Psychological Measurement, 66 (6), 1023-1038. doi: 10.1177/0013164406288167

Cardozo, A. (2008). Motivación, aprendizaje y rendimiento académico en estudiantes de primer año universitario [Motivation, learning and academic achievement in college freshmen]. Revista de Educación, 14 (28), 209-237.

Casillas, A., Robbins, S., Allen, J., Kuo, Y., Hanson, M. A., \& Schmeiser, C. (2012). Predicting early academic failure in high school form prior academic achievement, psychosocial characteristics and behavior. Journal of Educational Psychology, 104 (2), 407-420. doi: 10.1037/a0027180

Dansereau, D. F. (1985). Learning strategy research. In J. W. Segal, S. F. Chipman \& R. Glaser (Eds.), Thinking and learning skills: Relating instruction to research (pp. 209-241). New Jersey: Lawrence Erlbaum Associates. 
Deci, E. L., \& Ryan, R. M. (1985). Intrinsic motivation and self-determination in human behavior. New York: Plenum Press.

Deci, E. L., \& Ryan, R. M. (2004). Handbook of self-determination research. New York: University of Rochester Press.

de la Fuente, J., \& Justicia, F. (2003). Escala de estrategias de aprendizaje ACRA-Abreviada para alumnos universitarios [Learning strategies Scales ACRA-Short Version for college students]. Revista Electrónica de Investigación Psicoeducativa y Psicopedagógica, 1(2), 139-158.

Faye, C., \& Sharpe, D. (2008). Academic Motivation in university: The role of basic psychological needs and identity formation. Canadian Journal of Behavioural Science, 50 (4), 189-199. doi: 10.1037/ a0012858

Fernández Liporace, M., Scheinsohn, M. J., \& Uriel, F. (2010) Análisis factorial exploratorio del Inventario de Estrategias de Aprendizaje y Estudio - LASSI [Exploratory Factor Analysis for the Learning and Stydy Strategies Inventory-LASSI-]. Memorias del I Congreso Internacional de Psicología y Educación (CD) [I International Congress of Psychology and Education, Memoires in CD]. Panamá, Panamá: Psychology Investigation Corp.

Formichella, M. M. (2009). Una explicación de las trampas de pobreza. El círculo vicioso entre el nivel de educación y el nivel de ingresos [An explanation of poverty traps. The vicious circle of educational level and income level]. Estudios Económicos, 26 (52), 49-80.

Fortier, M. S., Vallerand, R. J., \& Guay, F. (1995). Academic Motivation and school performance: Toward a structural model. Contemporary Educational Psychology, 20, 257-274. doi: 10.1006/ ceps. 1995.1017

Furlan, L. A., Sánchez, J., \& Heredia, D. (2009). Estrategias de aprendizaje y ansiedad ante los exámenes en estudiantes universitarios [Learning strategies and test anxiety in college students]. Pensamiento Psicológico, 5 (12), 117-124.

García de Fanelli, A., \& Jacinto, C. (2010). Equidad y educación superior en América Latina: El papel de las carreras terciarias y universitarias [Equity and superior education in Latin America: The role of technical careers and of colleges]. Revista Iberoamericana de Educación Superior, 1 (1), 58-75.

Gargallo, B., Suárez, J., \& Ferreras, A. (2007). Estrategias de aprendizaje y rendimiento académico en estudiantes universitarios. [Learning strategies and academic achievement in college students]. Revista de Investigación Educativa, 25(2), 421-441.

Gázquez, J. J., Pérez, M. C., Ruiz, M. I., Miras, F., \& Vicente, F. (2006). Estrategias de aprendizaje en estudiantes de enseñanza secundaria obligatoria y su relación con la autoestima [Learning strategies in high school students and its relationship with self-esteem]. International Journal of Psychology and Psychological Therapy, 6 (1), 51-62.

Goldenhersh, H., Coria, A., \& Saino, M. (2011). Deserción estudiantil: desafíos de la universidad pública en un horizonte de inclusión [Educational dropout: Challenges for public universities regarding inclusion]. Revista Argentina de Educación Superior, 3 (3), 96-120.

Grolnick, W. S., Ryan, R. M., \& Deci, E. L. (1991). Inner resources for school achievement: Motivational mediators of children's perception of their parents. Journal of Educational Psychology, 83 (4), 508517. doi: $10.1037 / 0022-0663.83 .4 .508$

Guay, F., \& Vallerand, R. J. (1997). Social context, student's motivation, and academic achievement: Toward a process model. Social Psychology of Education, 1, 211-233.

Hernández-Sampieri, R., Fernández-Collado, C., \& Lucio, P. B. (2006). Metodología de la investigación. Cuarta edición. [Methodology of research. Fourth Edition]. México D. F.: McGraw-Hill.

Jang, H., Reeve, J., Ryan, R. M., \& Kim, A. (2009). Can self-determination theory explain what underlies the productive, satisfying learning experiences of collectivistically oriented Korean students? Journal of Educational Psychology, 101 (3), 644-661. doi: 10.1037/a0014241

Kline, R. B. (1998). Principles and practice of structural equation modeling. New York: Guilford. 
Kusurkar, R. A., Ten Cate, T. J., Vos, C. M., \& Westers, P (2012). How motivation affects academic performance: A structural equation modelling analysis. Advance in Health Science Education. doi: 10.1007/ s10459-012-9354-3

Lévy, J., \& Varela Mallou, J. (2006). Modelización con estructuras de covarianzas en ciencias sociales [Covariance structures modellization in Social Sciences]. La Coruña: Netbiblo.

Liu, O. L. (2009). Evaluation of a Learning strategies scale for middle school students. Journal of Psychoeducational Assessment, 27 (4), 312-322. doi: 10.1177/0734282908327935

Liu, W. C., Wang, C. K. J., Tan, O. S., Kohn, C., \& Ee, J. (2009). A self-determination approach to understanding student's motivation in project work. Learning and Individual Differences, 19, 139-145. doi: 10.1016/j.lindif.2008.07.002

Looker, E. D. (1989). Accuracy of proxy reports of parental status characteristics. Sociology of Education, 62 (4), 257-276. doi: $10.2307 / 2112830$

Loong, T. E. (2012). Self-regulated learning among low-, average-, and high-math achievers among preuniversity international students in Malaysia. European Journal of Social Sciences, 30 (2), 302-312.

Martín, E., García, L. A., Torbay, A., \& Rodríguez, T. (2008). Estrategias de aprendizaje y rendimiento académico en estudiantes universitarios [Learning strategies and academic achievement in college students]. International Journal of Psychology and Psychological Therapy, 8 (3), 401-412.

Ministerio de Educación [Ministry of Education]. (2010). Operativo Nacional de Evaluación 2010. Censo de finalización de la educación secundaria. Informe de resultados. [National Assessment Device. Census on finalization of high school level. Results report]. Retrieved 20/09/2012, from http://diniece.me.gov.ar/images/stories/diniece/evaluacion_educativa/nacionales/resultados/Resultados\%20 Censo\%20ONE\%202010.pdf

Ministerio de Educación [Ministry of Education]. (2012). Operativo Nacional de Evaluación 2010. $2^{\circ} / 3^{\circ}$ año de la Educación Secundaria. Informe de Resultados. [National Assessment Device 2010. $2^{\circ} / 3^{\circ}$ courses high school. Results report]. Retrieved 22/09/2012, from http://iniece.me.gov.ar/images/stories/diniece/ evaluacion_educativa/nacionales/resultados/informe_resumen_febrero_2012.pdf

Monereo, C. (1990). Las estrategias de aprendizaje en la educación formal: enseñar a pensar y sobre el pensar [Learning strategies in formal education: Teaching to think and about thinking]. Infancia $y$ Aprendizaje, 50, 3-25.

Montanero, M., \& León, J. A. (2001). Acepciones "sustantiva" y "adjetiva" del concepto de estrategia ["Substantive" and "Adjective" meanings of the concept of strategy]. Estudios de Psicología, 22 (3), 345-356. doi: 10.1174/021093901753581385

Mouratidis, A., Vansteenkiste, M., Michou, A., \& Lens, W. (2013). Perceived structure and achievement goals as predictors of students' self-regulated learning and affect and the mediating role of competence need satisfaction. Learning and Individual Differences, 23, 179-186. doi: 10.1016/j.lindif.2012.09.001

Ng, J. Y. Y., Ntoumanis, N., Thogersen-Ntoumani, C., Deci, E. L., Ryan, R., Duda, J. L., \& Williams, G. C. (2012). Self-determination theory applied to health contexts: A meta-analysis. Perspectives on Psychological Science, 74 (4), 325-340. doi: 10.1177/1745691612447309

Nisbet, J., \& Shucksmith, J. (1987). Estrategias de aprendizaje [Learning strategies]. Madrid: Santilllana.

OEDC (2013). PISA 2012. Results in Focus. Retrieved 20/12/2013 from http://www.oecd.org/pisa.

Oliver, M. C., Eimer, G. A., Bálsamo, N. F., \& Crivello, M. E. (2011). Permanencia y abandono en química general en las carreras de ingeniería de la Universidad Tecnológica Nacional - Facultad Regional Córdoba (UTN-FRC), Argentina [Continuity and drop-out in General Chemistry in Engineering careers of National Technological University]. Avances en Ciencia e Ingeniería, 2(2), 117-129.

Otis, N., Grouzet, F. M. E., \& Pelletier, L. G. (2005). Latent motivational change in an academic setting: A 3-year longitudinal study. Journal of Educational Psychology, 97 (2), 170-183. doi: 10.1037/00220663.97.2.170 
Pokay, P., \& Blumenfeld, P. C. (1990). Predicting achievement early and late in the semester: The role of motivation and use of learning strategies. Journal of Educational Psychology, 82 (1), 41-50. doi: 10.1037/0022-0663.82.1.41

Ratelle, C. F., Guay, F., Vallerand, R. J., Larose, S., \& Senécal, C. (2007). Autonomous, controlled, and amotivated types of Academic Motivation: A person-oriented analysis. Journal of Educational Psychology, 99 (4), 734-746. doi: 10.1037/0022-0663.99.4.734

Richardson, M., Abraham, C., \& Bond, R. (2012). Psychological correlates of university students' academic performance: A systematic review and meta-analysis. Psychological Bulletin, 138 (2), 353-387. doi: $10.1037 / \mathrm{a} 0026838$

Rinaudo, M. C., Chiecher, A., \& Donolo, D. (2003). Motivación y uso de estrategias en estudiantes universitarios. Su evaluación a partir del Motivated Strategies Learning Questionnaire [Motivation and use of strategies in college students: Their assessment by the Motivated Strategies Learning Questionnaire]. Anales de Psicología, 19 (1), 107-119.

Rinaudo, M. C., de la Barrera, M. L., \& Donolo, D. (2006). Motivación para el aprendizaje en estudiantes universitarios. Retrieved 06/02/2014, from http://reme.uji.es/articulos/numero22/article2/num\%20 22\%20article\%202\%20ArticMotivparaREME.PDF

Ryan, M. R., \& Deci, E. L. (2000). Self-determination theory and the facilitation of intrinsic motivation, social development, and well-being. American Psychological, 55 (1), 68-78. doi: 10.1037/0003-066X.55.1.68

Sheldon, K. M., \& Krieger, L. S. (2007). Understanding the negative effects of legal education on law students: A longitudinal test of self-determination theory. Personality and Social Psychology Bulletin, 33 (6), 883-897. doi: 10.1177/0146167207301014

Stover, J. B. (2012). Motivación, estrategias de aprendizaje y rendimiento académico en estudiantes medios y universitarios [Motivation, learning strategies and academic achievement in highschool and college students]. Doctoral Dissertation. School of Psychology. UBA.

Stover, J. B., de la Iglesia, G., Rial Boubeta, A., \& Fernández Liporace, M. (2012). Academic Motivation scale (AMS): Adaptation and psychometric analyses for high school and college students. Psychology Research and Behavior Management, 5, 71-83. doi: 10.2147/PRBM.S33188

Stover, J. B., Uriel, F., \& Fernández Liporace, M. (2012). Inventario de estrategias de aprendizaje y estudio: Análisis psicométrico de una versión abreviada [Learning and study strategies: A psychometric analysis of its short version]. Revista Argentina de Ciencias del Comportamiento, 4(3), 4-12.

Valle, A., Barca, A., González, R., \& Núñez, J. C. (1999). Las estrategias de aprendizaje. Revisión teórica $\mathrm{y}$ conceptual [Learning strategies. Theoretical and conceptual revision]. Revista Latinoamericana de Psicología, 31(3), 425-461.

Vallerand, R. J., Blais, M. R., Briere, N. M., \& Pelletier, L. G. (1989). Construction et validation de l'Echelle de Motivation en Éducation (EME) [Development and validation of the Academic Motivation Scale]. Canadian Journal of Behavioural Science, 21, 323-349. doi: 10.1037/h0079855

Vallerand, R. J., Fortier, M. S., \& Guay, F. (1997). Self-determination and persistence in a real-life setting: Toward a motivational model of high school dropout. Journal of Personality and Social Psychology, 72 (5), 1161-1176. doi: 10.1037/0022-3514.72.5.1161

Vansteennkiste, M., Zhou, M., Lens, W., \& Soenens, B. (2005). Experiences of autonomy and control among Chinese learners: Vitalizing or immobilizing? Journal of Educational Psychology, 97 (3), 468-483. doi: 10.1037/0022-0663.97.3.468

Vittorio, G., Fida, R., Vecchione, M., Del Bove, G., Vecchio, G. M., Barbaranelli, C., \& Bandura, A. (2008). Longitudinal analysis of the role of perceived self-efficacy for self-regulated in academic continuance and achievement. Journal of Educational Psychology, 100 (3), 525-534.

Weinstein, C. E., Husman, J., \& Dierking, D. R. (2000). Self - regulation. An introductory overview. In M. Boekaerts, P. R. Pintrich \& M. Zeidner (Eds.), Handbook of self-regulation (pp. 727-747). San Diego, CA, US: Academic Press. 
Juliana Beatriz STOVER, Agustín Freiberg HOFFMANN, Guadalupe de la IGLESIA, Mercedes Fernández LIPORACE. Predicting Academic Achievement: The Role of Motivation and Learning Strategies

Weinstein, C. E., Schulte, A. C., \& Palmer, D. R. (1987). Learning and Study Strategies Inventory (LASSI). Clearwater. Fl: H \& H Publishing.

Yip, M. C. W. (2007). Differences in learning and study strategies between high and low achieving university students: A Hong Kong study. Educational Psychology, 27 (5), 597-606. doi: $10.1080 / 01443410701309126$

Advised by Stanislava Yordanova Stoyanova, South-West University "Neofit Rilski”, Bulgaria

Received: January 30, 2014

Accepted: March 14, 2014

\begin{tabular}{|c|c|}
\hline Juliana Beatriz Stover & $\begin{array}{l}\text { Ph.D., Assistant Professor, University of Buenos Aires, School of Psychology, Gral. } \\
\text { Juan Lavalle 2353, Buenos Aires, Argentina. } \\
\text { E-mail: julianastover@psi.uba.ar }\end{array}$ \\
\hline Agustín Freiberg Hoffmann & $\begin{array}{l}\text { Ph.D Fellowship, Assistant Teacher, University of Buenos Aires, School of } \\
\text { Psychology, Gral. Juan Lavalle 2353. Buenos Aires, Argentina. } \\
\text { E-mail: afreiberg@psi.uba.ar }\end{array}$ \\
\hline Guadalupe de la Iglesia & $\begin{array}{l}\text { Ph.D., Assistant Professor, University of Buenos Aires, School of Psychology and } \\
\text { National Research Council (CONICET), Gral. Juan Lavalle 2353, Buenos Aires, } \\
\text { Argentina. } \\
\text { E-mail: gdelaiglesia@psi.uba.ar }\end{array}$ \\
\hline Mercedes Fernández Liporace & $\begin{array}{l}\text { Ph.D., Professor, Senior Researcher, University of Buenos Aires, School of } \\
\text { Psychology and National Research Council (CONICET), Gral. Juan Lavalle } 2353 . \\
\text { Buenos Aires, Argentina. } \\
\text { E-mail: mliporac@psi.uba.ar }\end{array}$ \\
\hline
\end{tabular}

